ISSN 0103-5150

Fisioter. Mov., Curitiba, v. 26, n. 1, p. 183-190, jan./mar. 2013

Licenciado sob uma Licença Creative Commons

\title{
Pelvic floor muscle training decreases hip adductors isometric peak torque in incontinent women: an exploratory study
}

\author{
Treinamento dos músculos do assoalho pélvico diminui \\ o pico de torque isométrico de adutores de quadril em \\ mulheres incontinentes: estudo exploratório
}

\section{Grasiéla Nascimento Correia $^{[a]}$, Cristine Homsi Jorge Ferreira ${ }^{[b]}$, Mariana Chaves Aveiro ${ }^{[c]}$, Vanessa Santos Pereira ${ }^{[\mathrm{d}]}$, Patricia Driusso ${ }^{[\mathrm{e}]}$}

[a] Ph.D. student of Physiotherapy Department at Federal University of São Carlos (UFSCar), São Carlos, SP - Brazil, e-mail: grasiela_n_correia@yahoo.com.br

[b] Professor of the Department of Biomechanics, Medicine and Rehabilitation of Locomotor System of Faculty of Medicine of Ribeirão Preto, Physiotherapy Post-Graduation Program (Rehabilitation and Functional Performance) at University of São Paulo (USP), Ribeirão Preto, SP - Brazil, e-mail: cristine@fmrp.usp.br

[c] Professor of Human Movement Sciences Department at Federal University of São Paulo (Unifesp), Santos, SP - Brazil, e-mail: mariaveiro@yahoo.com

[d] Ph.D. student of Physiotherapy at Federal University of São Carlos (UFSCar), São Carlos, SP - Brazil, e-mail: vanft05@yahoo.com.br

[e] Physiotherapy professor at Federal University of São Carlos (UFSCar), São Carlos, SP - Brazil, e-mail: pdriusso@ufscar.br

\begin{abstract}
Introduction: The pelvic floor muscle (PFM) training is the most common treatment for urinary incontinence (UI), however many women performed the contraction of PFM with associated contraction of abdominal, gluteus and hip adductors muscles. Objective: To assess the effects of pelvic floor muscle (PFM) training on isometric and isokinetic hip adductors peak torque (PT) among women suffering from urinary incontinence (UI). Materials and methods: It is a longitudinal and prospective exploratory study. This study included 15 physically active women aged 45 years old and over, who presented complaints of UI. The PFM function (digital evaluation and perineometry), isometric and isokinetic hip adductors PT and one hour pad test were performed before and after treatment. The PFM training was performed in group, one hour once a week for 12 sessions. Results: Significant improvement of PFM function and pressure level ( $p=0.003$ ), and significant decrease of hip adductors isometric PT and one-hour pad test, were found post-treatment. Moderate negative correlations
\end{abstract}


between PFM contraction pressure and hip adductors isokinetic PT for dominant side (DS) ( $r=-0.62 ; \mathrm{p}=0.03)$ and non-dominant side (NDS) ( $r=-0.64 ; \mathrm{p}=0.02)$; and between PFM fast fibers contraction and hip adductors isometric PT for DS ( $r=-0.60 ; p=0.03)$ and NDS ( $r=-0.59 ; p=0.04)$ were also found. Conclusions: The PFM training decreased hip adductors PT and improved PFM functions and UI.

Keywords: Urinary incontinence. Pelvic floor. Torque. Group therapy. Physiotherapy.

\section{Resumo}

Introdução: O treinamento dos músculos do assoalho pélvico (MAP) é o tratamento mais comum para incontinência urinária (IU), entretanto a maioria das mulheres realiza a contração dos MAP associada com a contração do abdominal, glúteos e adutores de quadril. Objetivos: Avaliar os efeitos do treinamento dos MAP no pico de torque (PT) isométrico e isocinético de adutores de quadril em mulheres com incontinência urinária (IU). Materiais e métodos: Estudo longitudinal, exploratório e prospectivo. Foram incluídas 15 mulheres com IU, fisicamente ativas, com idade superior a 45 anos. A função dos MAP (avaliação digital e perineometria), o PT isométrico e isocinético de adutores de quadril e oteste do absorvente de uma hora foram realizadas antes e após o tratamento. $O$ treinamento dos MAP foi em grupo, com duração de 12 sessões, uma hora por semana. Resultados: Houve aumento significativo da função e da pressão de contração $(p=0,003)$ dos MAP, e diminuição significativa do PT de adutores de quadril e do teste do absorvente de uma hora após o tratamento. Houve correlação negativa moderada entre a pressão de contração dos MAP e o PT isocinético de adutores de quadril do lado dominante (LD) ( $r=-0,62 ; p=0,03)$ e não dominante (LND) $(r=-0,64 ; p=0,02)$; e entre contração de fibras rápidas dos MAP e o $P T$ isométrico de adutores de quadril do LD ( $r=-0,60 ; p=0,03)$ e LND $(r=-0,59 ; p=0,04)$. Conclusão: $O$ treinamento dos MAP diminuiu o PT de adutores de quadril, melhorou a função dos MAP e da IU.

Palavras-chave: Incontinência urinária. Assoalho pélvico. Torque. Terapia em grupo. Fisioterapia

\section{Introduction}

In clinical practice, pelvic floor muscle training (PFM) is the most common treatment for urinary incontinence (UI), as they are cheaper, noninvasive, effective and do not present undesirable collateral effects. However, many women do not perform these exercises correctly, for they usually contract the abdominal, glutea and hip adductors muscles along with PFM (1-4). This difficulty women present may be due to their unwontedness to contract the PFM group voluntarily (1-4). Thus, they perform the PFM contractions with synergistic actions of other muscles with adjacent muscular insertions (5). Literature shows a relationship between PFM and abdominal, glutea and hip adductors contractions. Nonetheless, to our knowledge, there are no studies that evaluated the effects of PFM training on the hip adductors isometric and isokinetic peak torque (PT).

In this context, the hypothesis of this study was that PFM training would change hip adductors PT and improve function and pressure level of PFM among physically active women with UI. The purpose of this exploratory study was to assess the effects of a group-based PFM training on hip adductors isometric and isokinetic PT, PFM function and pressure level among women suffering from UI.

\section{Materials and methods}

This was a longitudinal and prospective exploratory study with a convenience sample. The Ethics Committee for Human Research of the University approved the study (report \# 180/2008), which is in agreement with the Declaration of Helsinki and the Resolution n. 196/96 from National Health Council. Study procedures were explained to all volunteers and an informed consent term was obtained before any procedure. The study was developed from August 2008 to June 2009.

Fifteen physically active women aged 45 years old and over, who presented more than one episode of urinary loss in last month and had never undergone physical therapy for UI treatment were included in the study. Women were considered physically active 
if they performed 150 minutes or more of physical activity per week (6). Women presenting latex allergy, urinary and vaginal infection, inadequate vagina size to introduce perineometer probe, levels 3 or 4 pelvic prolapse, incapacity of perform voluntary contraction of PFM, neurologic or cognitive impairment, uncontrolled systemic arterial hypertension and some disability that could impair evaluation or treatment were excluded from the study (Figure 1).

Participants were evaluated by the same physical therapist at the beginning of the study and after treatment. Each volunteer's assessment included one clinical evaluation, one-hour pad test, digital and perineometer evaluation for PFM function and hip adductor isometric and isokinetic PT.

The one-hour pad test was carried out as the participants were instructed to place a pad, previously weighed on a precision weighing-machine (Denver instrument APx-200, New York, United States), and then drink $500 \mathrm{ml}$ of water. After 30 minutes, they started performing a series of provocative exercises, accordingly to Abrams protocol (7), and at the end of one hour, the pad was removed, reweighed and the urinary loss was calculated. If urinary loss was greater than $1 \mathrm{~g}$, the test was considered positive for UI (7).

Digital assessment of PFM (8) was performed with lubricating gel and sterile gloves, with participants in supine position covered by sheets and with knees flexed. In this position, the evaluator introduced two fingers up to one third of the vagina and then instructed participants to perform maximum PFM contraction. This test was carried out by a single physical therapist in order to minimize possible measurement errors. The Modified Oxford Grading Scale by Laycock (9) was chosen to grade muscle strength.

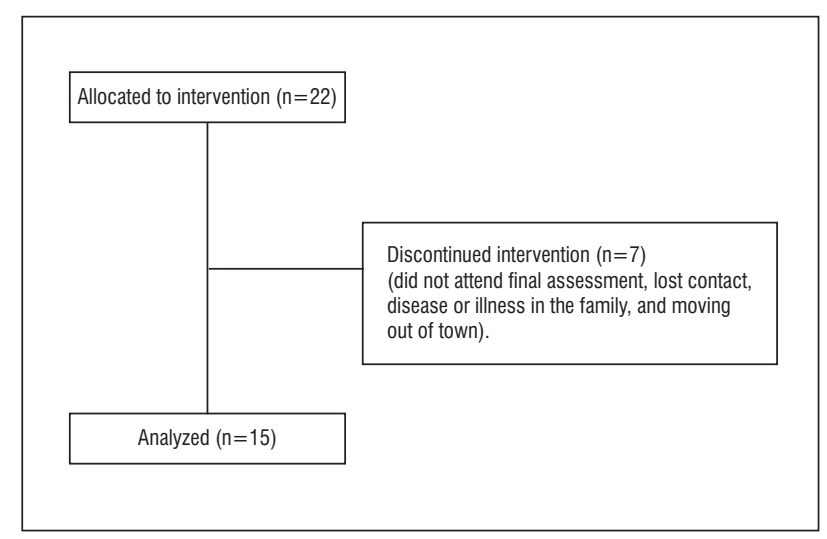

Figure $\mathbf{l}$ - Flow chart for volunteers' recruitment Source: Research data.
The perineometer Perina (Quark Medical Products, Piracicaba, Brazil), graded from 0 to $60 \mathrm{cmH}_{2} \mathrm{O}$ was used. Participants were placed at lithotomy position and the vaginal probe, previously covered by a con$\operatorname{dom}\left(\right.$ Microtex $\left.^{\circledR}\right)$ and lubricated $\left(\mathrm{K}-\right.$ med $^{\circledR}$ gel), was introduced $3.5 \mathrm{~cm}$ into the vagina. The equipment was then calibrated. Initially, participants performed two PFM contractions for familiarization with the procedures. After that, they performed a third contraction, which was the one considered for data analysis. PFM contractions were performed for three seconds (10). They were instructed to avoid performing abdominal, gluteus and hip adductors muscles contractions during maximum PFM evaluation $(10,11)$.

Hip adductors isometric and isokinetic PT were evaluated in the Biodex Multi-Joint System II isokinetic dynamometer. Tests were performed in the side-lying position, with the non-tested hip and knee flexed and fixed with straps. The dynamometer axis was aligned with the midpoint of the line linking the posterior superior iliac spine and the greater trochanter. The lever arm of the dynamometer was attached $5 \mathrm{~cm}$ above the superior patella border with straps $(12,13)$.

Initially, the dominant side, determined as the lower limb mostly used to kick a ball, was evaluated. Three 5-s isometric contractions with the hip at $30^{\circ}$ of abduction were performed, with a 10 -s rest period between them. Then, volunteers performed five isokinetic concentric contractions at $60 \%$ s, with a range of motion set from $0^{\circ}$ (neutral position) to $30^{\circ}$ of hip abduction (13). After that, the non-dominant side was tested in the same fashion as the dominant side.

The PFM Training Group was formed by all participants, and consisted of 121 -h sessions performed once a week in groups of 8-10 people. Exercises to strengthen PFM, information and guidance for UI were part of the treatment sessions. Initially, exercises were performed at supine and seated positions. Exercises evolved gradually, either by increasing the number of repetitions and/or the contraction time. Exercises then evolved to orthostatic position, squat and main situations that could induce urinary loss. Besides exercises, volunteers received basic information about UI, urinary system anatomy, self-care and food habits that could contribute to treatment.

The statistical analyses were performed using nonparametric tests, as the Shapiro-Wilk test showed a non-normal distribution of the variables. Comparisons between before and after treatment 
were made with the Wilcoxon test. Correlations between variables were performed by Spearman coefficient correlation. The level of significance used for all comparisons was $5 \%(\mathrm{p} \leq 0.05)$. The data are expressed as means \pm standard deviations. Data analysis was performed with Statistica 7.0 software (Statsoft. Inc ${ }^{\oplus} 1984-2004$ ).

\section{Results}

Twenty-two women were included in the initial group, but only 15 completed the treatment protocol (Figure 1). Age ranged from 46 to 75 years old (60.20 \pm 8.16$)$, and Body Mass Index (BMI) ranged from 18.73 to $32.76 \mathrm{Kg} / \mathrm{m}^{2}(26.30 \pm 3.32)$.

After PFM training, $60 \%$ women became urinary continent. There was significant decrease in urinary loss measured by the one-hour pad test $(\mathrm{p}=0.03)$; and an increase in PFM function, measured by perineometer $(p=0.005)$ and the PERFECT $(p \leq 0.001)$ after treatment (Table 1).

There was a significant decrease in hip adductors isometric PT for dominant ( $p=0.04)$ and non-dominant $(p=0.02)$ sides after treatment (Table 2). Hip abductors isometric PT did not present significant differences after PFM training (Table 2).

No correlation between the initial evaluations was found; nonetheless, moderate negative correlations between PFM contraction pressure and hip adductors isokinetic PT for dominant side $(\mathrm{r}=-0.62 ; \mathrm{p}=0.03)$ and non-dominant side $(\mathrm{r}=-0.64 ; \mathrm{p}=0.02)$; and between contraction force of PFM fast fibers (fast) and hip adductors isometric PT for dominant side $(r=-0.60 ; p=$ $0.03)$ and non-dominant side $(r=-0.59 ; p=0.04)$ were found at the end of the treatment (Table 3).

Table 1 - Outcomes of one-hour pad test, pelvic floor muscle function digital (PERFECT) and perioneometer

\begin{tabular}{lccc}
\hline & Pre-treatment & Post-treatment & $\mathbf{p}$ \\
\hline One hour pad test & $1.88 \pm 2.85$ & $0.46 \pm 0.45$ & $\mathbf{0 . 0 0 3}$ \\
Perineometer & $26.37 \pm 24.92$ & $41.13 \pm 18.77$ & $\mathbf{0 . 0 0 5}$ \\
PERFECT & & & \\
Power & $1.93 \pm 1.33$ & $3.07 \pm 0.70$ & $<\mathbf{0 . 0 0 1}$ \\
Endurance & $4.53 \pm 3.89$ & $8.87 \pm 1.85$ & $<\mathbf{0 . 0 0 1}$ \\
Repetition & $3.07 \pm 3.28$ & $8.27 \pm 2.31$ & $<\mathbf{0 . 0 0 1}$ \\
Fast fibers & $5.27 \pm 4.01$ & $9.20 \pm 1.70$ & $\mathbf{0 . 0 0 1}$ \\
\hline
\end{tabular}

Source: Research data.

Table 2 - Isometric and isokinetic hip abductors and adductors peak torque

\begin{tabular}{llll}
\hline & Pre-treatment & Post-treatment & p \\
\hline Isometric hip abductors PT ND & $17.45 \pm 8,58$ & $21.56 \pm 14.60$ & 0.12 \\
Isometric hip abductors PT D & $16.09 \pm 12.13$ & $21.31 \pm 15.04$ & 0.10 \\
Isokinetic hip abductors PT ND & $28.41 \pm 8.56$ & $28.31 \pm 10.51$ & 0.48 \\
Isokinetic hip abductors PT D & $30.90 \pm 12,59$ & $28.86 \pm 11.36$ & 0.23 \\
Isometric hip adductors PT ND & $84.11 \pm 18.49$ & $76.40 \pm 16.60$ & $\mathbf{0 . 0 2}$ \\
Isometric hip adductors PT D & $84.26 \pm 24.04$ & $75.64 \pm 22.52$ & $\mathbf{0 . 0 4}$
\end{tabular}


Table 2 - Isometric and isokinetic hip abductors and adductors peak torque

\begin{tabular}{llll}
\hline & Pre-treatment & Post-treatment & p \\
\hline Isokinetic hip adductors PT ND & $48.44 \pm 21.58$ & $43.64 \pm 15.36$ & 0.16 \\
Isokinetic hip adductors PT D & $53.17 \pm 26.90$ & $49.46 \pm 23.99$ & 0.25 \\
\hline
\end{tabular}

Source: Research data.

Notes: PT = Peak torque; ND = Non-dominant; $\mathrm{D}=$ Dominant.

Table 3 - Correlation between final evaluation isometric and isokinetic hip adductors peak torque and one hour pad test, perineometer, pelvic floor muscle function digital

\begin{tabular}{lcccccccc}
\hline & \multicolumn{2}{c}{ Isometric ND } & \multicolumn{2}{c}{ Isometric D } & \multicolumn{2}{c}{ Isokinetic D } & \multicolumn{2}{c}{ Isokinetic ND } \\
\hline & $\mathrm{r}$ & $\mathrm{p}$ & $\mathrm{r}$ & $\mathrm{p}$ & $\mathrm{r}$ & $\mathrm{p}$ & $\mathrm{r}$ & $\mathrm{p}$ \\
One-hour pad test & -0.18 & 0.57 & -0.10 & 0.73 & 0.04 & 0.88 & -0.003 & 0.99 \\
Perineometer & -0.32 & 0.29 & -0.42 & 0.16 & $\mathbf{- 0 . 6 2}$ & $\mathbf{0 . 0 3}$ & $\mathbf{- 0 . 6 4}$ & $\mathbf{0 . 0 2}$ \\
PERFECT - Power & -0.38 & 0.22 & -0.42 & 0.17 & -0.45 & 0.13 & -0.50 & 0.09 \\
PERFECT-Endurance & -0.10 & 0.75 & -0.04 & 0.89 & 0.17 & 0.57 & 0.20 & 0.51 \\
PERFECT- Repeat & -0.26 & 0.40 & -0.03 & 0.91 & -0.26 & 0.40 & -0.20 & 0.51 \\
PERFECT- Fast & $\mathbf{- 0 . 5 9}$ & $\mathbf{0 . 0 4}$ & $\mathbf{- 0 . 6 0}$ & $\mathbf{0 . 0 3}$ & -0.49 & 0.10 & -0.27 & 0.38 \\
\hline
\end{tabular}

Source: Research data.

Notes: $\mathrm{D}=$ Dominant; $\mathrm{ND}=$ Non-dominant.

\section{Discussion}

In the present study, $60 \%$ women became urinary continents after PFM training. This result is in agreement with other studies $(4,10,14-17)$, which demonstrated that kinesiotherapy to strengthen the PFM presented good results for UI treatment, because strengthened the PFM (18-20), reducing the stress urinary incontinence and inhibited the involuntary contraction of the detrusor muscle $(21,22)$, decreasing the urge urinary incontinence.

The improvement of UI after the PFM training also is shown by other results found in this study, as: significant decreased of one-hour pad test, which agrees with Zanetti et al. (4) study; improvement in pressure level of PFM contraction, such as the studies of $B \varnothing$ et al. (11) and Sung et al. (1); and significant improvement PFM strength, as the study by Castro et al. (14).

However, the unpublished of this study is the significant decrease in hip adductors isometric PT and the negative correlations between hip adductors isokinetic PT and PFM contraction pressure, and between hip adductors isometric PT and PFM fast fibers contraction force after treatment. A possible explanation for this result is that volunteers were not sedentary and usually these women present urinary loss during physical activities (23-26), especially during those exercises that involve weight lifting or impact (27).

Due to urinary incontinence during physical actives, volunteers could have used the contracting abdominal, gluteus and hip adductors muscles in association to PFM (1-4) as a mechanism of urinary loss control during physical activities, increasing the hip adductors PT before of treatment. During PFM training, volunteers were instructed to avoid associated contractions, increasing the strength and pressure of contraction of PFM and decreasing associated contractions of hip adductor muscles after the training.

In literature it is clear the relationship between pelvic floor muscle with abdominal, gluteus and hip adductors muscles in women that never performed 
the PFM training (1-4). Probably these synergic contractions occur due the nearness of insertion gluteus, abdominal and hip adductors muscles with pelvic floor muscle (5), and these women when try to contract the PFM, also recruit muscle fibers of abdominal, gluteus and hip adductors.

With the result of this study we can suggest that physical activities performed by women aged more 45 years old should be associated with orientation and training of PFM contractions. This is important to prevent and avoid the UI during physical actives (28-31). However, due the difficulty to contract the PFM voluntarily, it is indicated that an expert physiotherapist perform the PFM training. This conduct is important for avoiding that women acquire the habit to contract the PFM with the abdominal, gluteus and hip adductors, for avoid the UI during the physic activities.

Future studies would be to compare hip adductors PT between sedentary and non-sedentary with and without IU women submitted to PFM training, to evaluate the hip adductors PT, before and after PFM training in these different situations. There is the need for studies with control group, larger number of participants, with homogeneous age and BMI and that could include electromyography to evaluate the results along with those from the isokinetic dynamometer of hip adductors at beginning and the end of PFM training.

This study presented some limitations. As it was not possible to carry out urodynamic exams, it was not identified the type of urinary incontinence women had. However, according to the systematic review conducted by Dumoulin \& Haysmith (32) and Thüroff et al. (33), PFM training should be the first option for stress, mixed and urge UI, which are the most common UI types in women. The digital PFM function and the perineometer were used as evaluation tools; nonetheless, the result of perineometer can be modified by intraabdominal pressure and the amount of air inflated in perineometer probe, affecting the results obtained.

\section{Conclusion}

In conclusion, the PFM training decreased isometric hip adductors PT, improved PFM function and UI. There was a negative correlation between isometric hip adductors PT and PFM strength at the end of treatment in non-sedentary women suffering from UI. Probably, before PFM training, these women used the hip adductor contraction to avoid the urinary loss and after the treatment the participants learned PFM contraction, resulting in the decrease of hip adductor usage and the increase of PFM strength.

\section{Acknowledgments}

During the period of elaboration of this study, the authors had support of CNPq (Conselho Nacional de Desenvolvimento Científico e Tecnológico) and Capes (Coordenação de Aperfeiçoamento de Pessoal de Nível Superior).

\section{References}

1. Sung MS, Hong JY, Choi YH, Balk SH, Yoon H. FES-Biofeedback versus intensive pelvic floor muscle exercise for the prevention and treatment of genuine stress incontinence. J Korean Med Sci. 2000;15(3):303-8. PMid:10895973.

2. Bø K, Sherburn M. Evaluation of female pelvic floor muscle function and strength. Phys Ther. 2005; 85(3):269-82. PMid:15733051.

3. Capelini MVC, Riccetto C, Dambros M, Tamanini JT, Herrmann V, Muller V. Pelvic floor exercises with biofeedback for stress urinary incontinence. Int Braz J Urol. 2006;32(4):462-9. doi:10.1590/ S1677-55382006000400015.

4. Zanetti MRD, Castro RA, Rotta AL, Santos PD, Sartori M, Girão MJBC. Impact of supervised physiotherapeutic pelvic floor exercises for treating female stress urinary incontinence. Sao Paulo Med J. 2007;125(5):265-9. doi:10.1590/S1516-31802007000500003.

5. Dângelo JG, Fattini CA. Anatomia humana sistêmica e segmentar. 2. ed. Rio de Janeiro: Atheneu; 1997. PMid:9423791.

6. Hallal PC, Dumith SC, Bastos JP, Reichert FF, Siqueira FV, Azevedo MR. Evolução da pesquisa epidemiológica em atividade física no Brasil: revisão sistemática. Rev Saúde Pública. 2007;41(3):453-60. doi:10.1590/ S0034-89102007000300018.

7. Abrams P, Blaivas JG, Stanton S, Andersen JT. The standardisation of terminology of lower urinary tract function. Neurourol Urodyn.1988;7:403-26. doi:10.1002/ nau.1930070502. 
8. Bø K, Larseb S. Classification and characterization of responders to pelvic floor muscle exercises for female stress urinary incontinence. Neurourol Urodyn. 1990;9:395-6. doi:10.1002/nau.1930090505.

9. Laycock, J. Assessment and Treatment of pelvic floor dysfunction [PhD thesis]. Bradford: Postgraduate School of Biomedical Sciences, University of Bradford; 1992.

10. Thompson JA, O’Sullivan PB, Briffa NK, Neumann P. Assessment of voluntary pelvic floor muscle contraction in continent and incontinent women using transperineal ultrasound, manual muscle testing and vaginal squeeze pressure measurements. Int Urogynecol J. 2006;17(6):624-30. doi:10.1007/ s00192-006-0081-2.

11. Bø K, Talseth T, Holme I. Single blind, randomised controlled trial of pelvic floor exercises, electrical stimulation, vaginal cones, and no treatment in management of genuine stress incontinence in women. BMJ.1999;318(7182):487-93. doi:10.1136/ bmj.318.7182.487.

12. Burnett CN, Betts EF, King WM. Reliability of isokinetic measurements of hip muscle torque in young boys. Phys Ther. 1990;70(4):244-9. PMid:2315387.

13. Nakagawa TH, Muniz TB, Baldon RM, Maciel CD, Reiff RBM, Serrão FV. The effect of additional strengthening of hip abductor and lateral rotator muscles in patellofemoral pain syndrome: a randomized controlled pilot study. Clin Rehabil. 2008;22(12):1051-60. doi:10.1177/0269215508095357.

14. Castro RA, Arruda RM, Zanetti MRD, Santos PD, Sartori MGF, Girão MJBC. Single-blind, randomized, controlled trial of pelvic floor muscle training, electrical stimulation, vaginal cones, and no active treatment in the management of stress urinary incontinence. Clinics. 2008;63(4):465-72. doi:10.1590/ S1807-59322008000400009.

15. Janssen CCM, Lagro-Janssen ALM, Felling AJA. The effects of physiotherapy for female urinary incontinence: individual compared with group treatment. BJU Int. 2001;87(3):201-6. doi:10.1046/ j.1464-410x.2001.02040.x.
16. Lajiness MJ, Wolfert C, Hall S, Sampselle C, Diokno AC. Group session teaching of behavioral modification program for urinary incontinence: establishing the teachers. Urol Nurs. 2007;27(2):124-7. PMid:17494451.

17. Arruda RM, Sousa GO, Castro RA, Sartori MGF, Baracat EC, Girão MJBC. Hiperatividade do detrusor: comparação entre oxibutinina, eletroestimulação funcional do assoalho pélvico e exercícios perineais. Estudo randomizado. Rev Bras Ginecol Obstet. 2007;29(9):4528. doi:10.1590/S0100-72032007000900003.

18. Moreno AL. Fisioterapia em Uroginecologia. Barueri: Editora Manole; 2004.

19. Balmforth JR, Mantle J, Bidmead J, Cardozo L. A prospective observational trial of pelvic floor muscle training for female stress urinary incontinence. BJU Int. 2006;98(4):811-7. doi:10.1111/ j.1464-410X.2006.06393.x.

20. Rett MT, Simões JA, Herrmann V, Gurgel MSC, Morais SS. Qualidade de vida em mulheres após tratamento da incontinência urinária de esforço com fisioterapia. Rev Bras Ginecol Obstet. 2007;23(3):134-40. doi:10.1590/S0100-72032007000300004.

21. Elser DM, Wyman JF, Mcclish DM, Robinson D, Fantl JA, Bump RC. The effect of bladder training, pelvic floor muscle training, or combination training on urodynamic parameters in women with urinary incontinence. Continence Program for Women Research Group. Neurourol Urodyn. 1999;18(5):427-36. doi:10.1002/(SICI)1520-6777(1999)18:5<427::AIDNAU3>3.0.CO;2-0.

22. Alewijnse D, Mesters IE, Metsemakers JF, Van Den Borne BH. Program development for promoting adherence during and after exercise therapy for urinary incontinence. Patient Educ Couns. 2002;48(2):14760. doi:10.1016/S0738-3991(02)00021-6.

23. Kulpa P. Conservative treatment of urinary stress incontinence. The Physician and Sportsmedicine. 1996;24(7). doi:10.3810/psm.1996.07.1398.

24. Caetano AS, Tavares MCGCF, Lopes MHBM. Urinary incontinence and physical activity practice. Rev Bras Med Esporte. 2007;13(4):270-4. doi:10.1590/ S1517-86922007000400012. 
25. Santos ES, Caetano AS, Tavares MCGCF, Lopes MHBM. Incontinência urinária entre estudantes de educação física. Rev Esc Enferm USP. 2009;43(2):307-12. doi:10.1590/S0080-62342009000200008.

26. Araujo MP, Oliveira E, Zucchi EV, Trevisani VF, Girão MJ, Sartori MG. The relationship between urinary incontinence and eating disorders in female long-distance runners. Rev Assoc Med Bras. 2008;54(2):146-9. PMid:18506324.

27. Eliasson K, Larsson T, Mattsson E. Prevalence of stress incontinence in nullipanous elite trampolinists. Scand J Med Sci Sports. 2002;12(2):106-10. doi:10.1034/j.1600-0838.2002.120207.x.

28. Vitton V, Baumstarck-Barrau K, Brardjanian S, Caballe I, Bouvier M, Grimaud JC. Impact of high-level sport practice on anal in continence in a healthy young female population. J Womens Health. 2011;20(5):757-63. doi:10.1089/jwh.2010.2454.

29. Jácome C, Oliveira D, Marques A, Sá-Couto P. Prevalence and impact of urinary incontinence among female athletes. Int J Gynaecol Obstet. 2011;114(1):60-3. doi:10.1016/j.ijgo.2011.02.004.

30. Bø K, Sundgot-Borgen J. Are former female elite athletes more likely to experience urinary incontinence later in life than non-athletes? Scand J Med Sci Sports. 2010;20(1):100-4. doi:10.1111/j. 1600-0838.2008.00871.x.
31. Salvatore S, Serati M, Laterza R, Uccella S, Torella M, Bolis PF. The impact of urinary stress incontinence in young and middle-age women practising recreational sports activity: an epidemiological study. Br J Sports Med. 2009;43(14):1115-8. doi:10.1136/ bjsm.2008.049072.

32. Dumoulin C, Haysmith J. Pelvic floor muscle training versus no treatment, or inactive control treatment, for urinary incontinence in women. Cochrane Database Syst Rev. 2010;20(1):CD005654.

33. Thüroff JW, Abrams P, Andersson KE, Artibani W, Chapple CR, Drake MJ, et al. EAU Guidelines on Urinary Incontinence. Actas Urol Esp. 2011;35(7):373-88. doi:10.4321/S0210-48062011000700001.

Received: 04/25/2012

Recebido: 25/04/2012

Approved: $12 / 22 / 2012$

Aprovado: 22/12/2012 